De Jure: Jurnal Hukum dan Syari'ah

Vol. 9, No. 1, 2017, h. 1-12

ISSN (Print): 2085-1618, ISSN (Online): 2528-1658

DOI: http://dx.doi.org/10.18860/j-fsh.v9i1.4063

Available online at http://ejournal.uin-malang.ac.id/index.php/syariah

\title{
Legalitas Nikah Sirrî Ditinjau Dari Kaidah Fikih
}

Fauzan Muhammadi

Fakultas Hukum Universitas Ahmad Dahlan, Yogyakarta

fauzan.muhammadi@law.uad.ac.id

\begin{abstract}
Abstrak:
Unrecorded marriage becomes legal issues in Indonesia after the government has obliged that marriage must be registered with the Registrar of Marriage Officers or the Office of Religious Affairs. The propnents of this marriage maintain that such marriage is considered valid and legal under Islamic law, although it is not admitted by the state law. The objective of this research is to discuss the legal problems of unrecorded marriage in Islamic law in the Indonesian context and to understand the changes of legal status of unrecorded marriage from the perspective of Islamic legal maxim. The methodology used in this research is descriptive-qualitative analysis. This study shows that according to the perspective of Islamic legal maxim, unrecorded marriage is not restricted but it may fall under the category of forbidden. It is because there are many deviations in a marriage when it is not registered. Thus, this could harm the family lived in the future.

Pasca pemerintah mengeluarkan kebijakan untuk mewajibkan pencatatan nikah di hadapan Kantor Urusan Agama (KUA)/Petugas Pencatat Nikah (PPN), nikah Sirrî menjadi isu hukum yang hangat di Indonesia. Permasalahan ini muncul sebagai bagian dari pemahaman masyarakat bahwa pernikahan mereka dianggap valid dan sah secara agama (hukum Islam) namun 'illegal' secara hukum positif. Studi ini berusaha untuk mendiskusikan legalitas nikah sirrî dalam hukum islam di Indonesia sekaligus untuk memahami probabilitas perubahan hukum nikah sirrî melalui Kaidah Fikih. Penelitian ini menggunakan analisa deskriptifkualitatif melalui studi literatur. Hasil dari studi ini adalah dimungkinkannya perubahan hukum nikah sirrî dari yang sebelumnya boleh menjadi haram. Ini berdasarkan fakta banyaknya penyimpangan wewenang pernikahan yang tidak tercatat yang merugikan kehidupan keluarga di masa yang akan datang.
\end{abstract}

Kata Kunci: nikah sirrî; kaidah fikih; pencatatan nikah. 


\section{Pendahuluan}

Nikah sirrî masih menjadi salah satu tema diskusi para ahli hukum Islam maupun hukum positif. ${ }^{1}$ Berbagai persoalan keluarga muncul sebagai akibat nikah sirrî, seperti kekerasan dalam rumah tangga, penelantaran dan ketidakpastian status hukum suami, istri, dan anak. ${ }^{2}$ Pembahasan nikah sirrî telah dilakukan para ahli hukum Islam dan memunculkan dua definisi nikah sirrî, antara lain: 1) uhli ikih dari kalanazhab Hanafi, Syafii, dan Hambali berpandangan, bahwa nikah sirrî adalah menikah tanpa dihadiri dua orang saksi. Perkawinan yang tidak dihadiri oleh saksi, menurut jumhur ulama dianggap tidak sah. Sebab, kehadiran saksi menjadi salah satu rukun dan syarat sah pernikahan; 2) Mazhab Maliki berpendapat, bahwa nikah sirrî adalah menikah dengan ketentuan syarat dan rukun pernikahan, akan tetapi kedua mempelai atau pihak keluarga berpesan kepada saksi agar merahasiakan berita pernikahan tersebut. ${ }^{3}$ Usaha menyembunyikan dan atau merahasiakan berita pernikahan yang rentan menimbulkan fitnah sehingga status hukumnya menjadi makruh. ${ }^{4}$

Definisi nikah sirrî yang saat ini dipahami oleh masyarakat Indonesia telah mengalami pergeseran. Nikah sirrî dipahami sebagai perkawinan yang dilaksanakan menurut rukun dan syarat yang ditetapkan dalam fiqh, tetapi tidak dihadiri dan dicatat oleh pegawai pencatat nikah dari Kantor Urusan Agama. ${ }^{5} \mathrm{Hal}$ ini didasarkan pada ketentuan Pasal 2 ayat (1) Undang-Undang Nomor 1 Tahun 1974 yang menyatakan bahwa setiap perkawinan dicatat berdasarkan ketentuan yang berlaku. Suatu perkawinan juga harus dihadiri oleh pegawai pencatat nikah sebagaimana diatur dalam Pasal 10 ayat (3) Peraturan Pemerintah Nomor 9 Tahun 1975 tentang Pelaksanaan Undang-Undang Nomor 1 Tahun 1974 tentang Perkawinan. Pencatatan perkawinan merupakan syarat sah tambahan karena Pasal 2 ayat (1) dan ayat (2) Undang-Undang Nomor 1 Tahun 1974 dipandang sebagai kesatuan yang tak terpisahkan. ${ }^{6}$

Pencatatan nikah dalam khazanah fiqh klasik belum mendapat perhatian khusus dari para fuqaha. Sebab, pencatatan perkawinan tidak didukung nash yang bersifat ekspisit. Sahnya akad perkawinan terletak pada terpenuhi atau tidaknya

\footnotetext{
1 Mahmud Syaltut, Al-Fatâwâ (DirâSah Li MusykilâTi'l Muslimi'l Mu'âShir Fî̀ HayâTihi'l Yaumiyati'l 'Âmmah) (Kairo: Al-Syuruq Pers, 2004), 232-34.

2 Thriwaty Arsal, "Woman's Position in Undocumented Marriages," Jurnal Komunitas: Research and Learning in Sociology and Anthropology 6, no. 1 (June 12, 2014): 27, doi:10.15294/komunitas.v6i1.2947.

${ }^{3}$ Kementrian Wakaf dan Agama Islam Kuwait, Al-Mausû' 'atul Fiqhiyyah, vol. 41 (Kuwait: Dar AlSalasil, 2002), 352-54.

${ }^{4}$ Kementrian Wakaf dan Agama Islam Kuwait, Al-Mausû'atul Fiqhiyyah, 41:354-55.

${ }^{5}$ Khoirul Hidayah, "Persoalan Hukum Perempuan Rembang Akibat Praktek Nikah Sirri," De Jure: Jurnal Hukum Dan Syariah 3, no. 1 (June 2011): 88, doi:10.18860/j-fsh.v3i1.1322.

${ }^{6}$ Amiur Nuruddin and Azhari Akmal Tarigan, Hukum perdata Islam di Indonesia: studi kritis perkembangan hukum Islam dari fikih, UU no. 1/1974, sampai KHI (Jakarta: Kencana, 2004), 134.
} 
rukun dan syarat. Meskipun demikian, pencatatan nikah yang diatur dalam UndangUndang Nomor 1 Tahun 1974 tentang Perkawinan dan Peraturan Pemerintah Nomor 9 Tahun 1975 tentang Pelaksanaan Undang-Undang Perkawinan merupakan respon atas berbagai perubahan yang terjadi dalam kehidupan sosial manusia, guna menciptakan kemaslahatan yang bersifat umum. Misalnya, melindungi kelompok rentan dari penyelewengan akad pernikahan atau penelantaran. Sementara itu, syariat Islam dalam aplikasi hukumnya memiliki sifat yang sering disebut shâlih li kulli zamânin wa makânin. Sifat elastis inilah yang kemudian menjadi wawasan awal mujtahid untuk senantiasa mengadaptasikan keputusan hukumnya pada ruang dan waktu. Penetapan dan perubahan hukum haruslah mempertimbangkan aspek kemaslahatan dan/atau kemanfaatan. Penetapan dan perubahan hukum juga membutuhkan analisa yang runtut disertai dalil-dalil yang argumentatif. Berdasarkan berbagai persoalan di atas, artikel ini berupaya menganalisis legalitas nikah sirrî di Indonesia berdasarkan fatwa Majelis Ulama Indonesia dan Muhammadiyah, baik dalam aspek hukum maupun dalil argumentatifnya

\section{Metode Penelitian}

Metode yang digunakan penulis dalam pengumpulan data adalah dengan studi pustaka (literature research). Metode ini dilakukan melalui pembacaan, kajian, dan penelitian bahan-bahan referensial seperti literatur atau buku, jurnal ilmiah, makalah atau artikel, dokumen perundang-undangan, dokumen fatwa, dan data-data tertulis lainnya yang berhubungan dengan objek penelitian. Data yang digunakan dalam penelitian dianalisa melalui metode deskriptif-kualitatif guna memperoleh gambaran sistematis dari cakupan permasalahan dengan berpijak pada pada teori dan definisi terkait.

\section{Hasil dan Pembahasan}

\section{Legalitas Nikah Sirrî dalam Hukum Islam}

Persoalan nikah sirrî dalam khazanah fikih klasik telah lama dikaji oleh para ulama. Ada banyak definisi mengenai nikah sirrî. Perbedaan ini dapat dijumpai dalam literatur-literatur fikih klasik. Pada Mazhab Hanafi, ${ }^{7}$ Mazhab Syafii, ${ }^{8}$ dan

\footnotetext{
${ }^{7}$ Alauddin Al-Kasani, Badâ ì' Al-Shanâ 'i’ Fî Tartîb Al-Syarâ i’, vol. 2 (Beirut: Darul Kitab AlArabi, 1982), 253. Pada kitab ini disebutkan secara tertulis tentang nikah sirrî, yaitu:

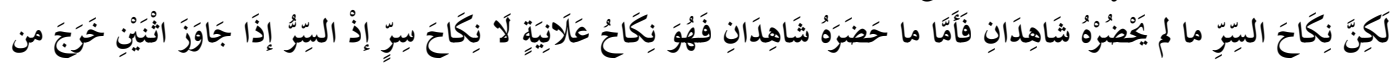
أَنْ يَكُونَ سِرَّا

${ }^{8}$ Ali bin Muhammad bin Habib Al-Mawardi, Al-HâWî̀'l Kabîr Fî Fiqh Madzhabi'l Imâm AlSyâFi'i, vol. 9 (Beirut: Darul Kutub Ilmiah, 1999), 59. Pada kitab ini disebutkan secara tertulis tentang nikah sirrî, yaitu:

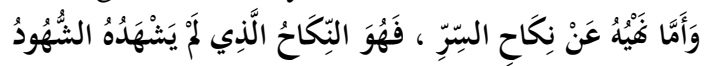


Mazhab Hambali ${ }^{9}$ dikemukakan, nikah sirrî adalah pernikahan yang tidak dihadiri dua orang saksi. Sedangkan menurut Mazhab Maliki, nikah sirrî adalah pernikahan yang diiringi permintaan kepada saksi untuk merahasiakan berita pernikahan. ${ }^{10}$ Dua pendapat tersebut bermula dari pemahaman terhadap hadis Rasulullah Saw yang menyatakan bahwa akad nikah tidak akan dianggap sah apabila tidak disaksikan oleh dua orang yang adil. Keberadaan saksi dalam akad nikah berfungsi sebagai alat publikasi pernikahan. Pemahaman ini juga didasarkan pada atsar sahabat Umar bin Khattab yang pernah menghadiri prosesi nikah dengan saksi seorang laki-laki dan perempuan, kasus ini kemudian dikomentari Umar dengan kalimatnya, "ini pernikahan sirrî'. ${ }^{11}$ Dalam khazanah fiqh, setidaknya ada dua pandangan terkait status nikah sirrî: Pertama, dihukumi haram jika tidak memenuhi syarat sah dan rukum pernikahan. seperti tidak ada wali dan saksi. Model perkawinan ini dapat dipidanakan sebagaimana keterangan Umar bin Khattab, "Ini nikah sirrî dan aku tidak membolehkannya, kalaupun aku hadir, niscaya aku terapkan hukum rajam (karena dianggap telah berzina)"; Kedua, dihukumi makruh jika syarat dan rukun nikah terpenuhi tetapi seorang wali atau mempelai berpesan agar saksi merahasiakan perkawinan. Bahkan status hukumnya dapat dibatalkan oleh pengadilan, baik itu sebelum atau sesudah berhubungan suami-isteri. ${ }^{12}$

Nikah sirrî juga terjadi di Indonesia. Model perkawinan ini lazim disebut nikah di bawah tangan, nikah modin, nikah kyai, atau nikah syar'i. ${ }^{13}$ Nikah sirrî didefinisikan sebagai pernikahan yang dilaksanakan sesuai dengan ketentuan agama Islam, namun tidak dicatatkan dihadiri oleh Petugas Pencatat Nikah (PPN) atau dicatat di Kantor Urusan Agama (KUA). Pernikahan model ini biasanya dilangsungkan secara sembunyi-sembunyi, rahasia, dan tertutup dari publikasi. ${ }^{14}$ Pemahaman ini muncul berdasarkan ketentuan Pasal 2 Undang-Undang Nomor 1

${ }^{9}$ Abu Ya'qub Al-Tamimi Al-Marwazi, Masầilu’l Imâm Ahmad Bin Hanbal Wa Ibni RâHawaih (Riyadh: Darul Hijrah, 2004), 427. Pada kitab ini disebutkan secara tertulis tentang nikah sirrî, yaitu: قال : أن لا يظهروه, وأن يزوجا بالأولياء قلت: نكاح السر ما هو؟

${ }^{10}$ Sayid Ahmad Dardir, Al-Syarhu'l Kabîr, vol. 2 (Beirut: Darul Fikri, n.d.), 236. Pada kitab ini disebutkan secara tertulis tentang nikah sirrî, yaitu:

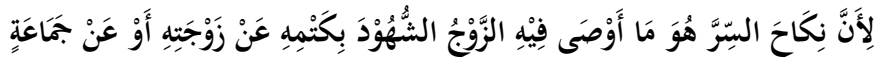

${ }^{11}$ Abu Bakar Ahmad ibn Husain ibn Ali al-Baihaqi, Al-Sunanu'l Kubra, vol. 7 (Makah: Darul Baz, 1994), 126. Riwayat hadis ini tertulis sebagai berikut:

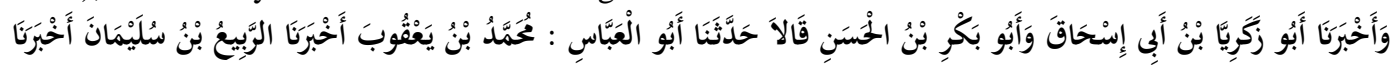

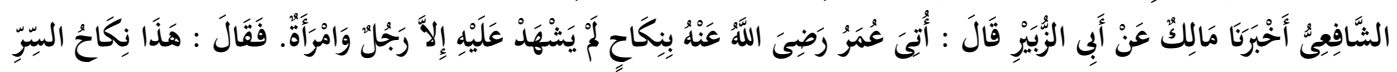

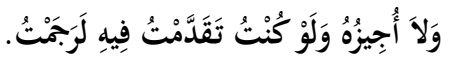

${ }^{12}$ Kementrian Wakaf dan Agama Islam Kuwait, Al-Mausû'atul Fiqhiyyah, 41:352-55.

${ }^{13}$ Abdul Ghofur Anshori, Hukum perkawinan Islam: perspektiffikih dan hukum positif (Yogyakarta: UII Press, 2011), 210.

${ }^{14}$ Masturiyah, "Nikah Sirri: Prespektif Hukum Islam Dan Hukum Perkawinan Nasional," MusâWa Jurnal Studi Gender Dan Islam 12, no. 1 (2013): 45, doi:http://dx.doi.org/10.14421/musawa.2013.121.43-62. 
tahun 1974 yang menyatakan bahwa perkawinan adalah sah apabila dilakukan menurut hukum masing-masing agama dan kepercayaannya itu. Selain itu, tiap-tiap perkawinan dicatat menurut peraturan perundang-undangan yang berlaku. Dalam pasal 10 ayat (3) Peraturan Pemerintah Nomor 9 Tahun 1975 tentang Pelaksanaan Undang-Undang Nomor 1 Tahun 1974 tentang Perkawinan juga dijelaskan bahwa tatacara perkawinan dilaksanakan menurut ajaran agama dan kepercayaan masingmasing. Dengan catatan perkawinan harus dilaksanakan dihadapan Pegawai Pencatat dan dihadiri oleh dua orang saksi.

Terdapat banyak varian nikah sirrî di Indonesia. Pertama, Pernikahan yang memenuhi syarat dan rukun sebagaimana diatur dalam khazanah fiqh tetapi tidak dicatatkan di Kantor Urusan Agama. Ketiga, perkawinan yang dilaksanakan dengan tidak memenuhi syarat dan rukun serta tidak dicatat di Kantor Urusan Agama. Keempat, perkawinan yang dicatat oleh pejabat yang tidak berwenang atau dengan akta perkawinan palsu. Berbagai model sirrî dengan berbagai status hukumnya menimbulkan persoalan hukum baru karena memberikan peluang penyelewengan dan dapat merugikan anggota keluarga. Misalnya, adanya penelantaran secara ekonomi oleh suami, sementara pihak istri atau anak-anak tidak memiliki kedudukan hukum untuk menuntut di pengadilan.

Dalam hukum Islam terdapat kaidah yang berbunyi "tidak diingkari adanya perubahan hukum karena perubahan zaman". ${ }^{15}$ Kaidah ini merupakan turunan dari kaidah induk: "Adat kebiasaan dapat menjadi acuan hukum". ${ }^{16}$ Kaidah ini kemudian menjadi prinsip elastisitas dan fleksibilitas penerapan hukum Islam, serta dapat digunakan sebagai acuan para penentu kebijakan agar sejalan hukum dengan pokok maslahat yang ada. Ahmad bin Muhammad al-Zarqa menjelaskan perubahan hukum merupakan konsekuensi dari perubahan kebiasaan atau kondisi. Apabila adat kebiasaan atau kondisi masyarakat berubah, berubah pula ketentuan hukum menyesuaikan dengan perubahan yang terjadi. Akan tetapi, perubahan hukum tersebut tidak berlaku bagi semua ketetapan dalam syariat. Misalnya ketetapan yang bersumber dari dalil yang qath'î bersifat tetap. Perubahan hukum akibat faktor zaman adalah segala hal yang terkait dengan permasalahan ijtihad, ${ }^{17}$ seperti kasus pencatatan dalam perkawinan

Pada praktik tersebut, beberapa organisasi massa Islam di Indonesia, seperti Majelis Ulama Indonesia (MUI) dan Muhammadiyah telah mengeluarkan fatwa terkait dengan nikah sirrî. Majelis Ulama Indonesia berpendapat, bahwa nikah sirrî yang dilakukan dengan memenuhi semua rukun dan syarat dalam hukum Islam, tetapi tidak dicatatkan oleh instansi yang berwenang hukumnya sah tetapi akan

15 Ya'qub bin Abdul Wahab Al-Bahisin, Al-Mufasshal Fi Al-Qawâ'id Al-Fiqhiyyah (Darut Tadammuriyah, 2011), 397.

${ }^{16}$ Al-Bahisin, Al-Mufasshal Fi Al-Qawâ'id Al-Fiqhiyyah, 459.

17 Ahmad bin Muhammad Al-Zarqa, Syarh Al-Qawâid Al-Fiqhiyyah (Damaskus: Darul Qalam, 1989), 227-28. 
menjadi haram jika menimbulkan mudarat. Untuk itu, pencatatan nikah harus dilakukan sebagai upaya preventif dari dampak negatif. ${ }^{18}$ Sedangkan Muhammadiyah menyatakan bahwa pernikahan atau perkawinan merupakan salah satu dari beberapa jenis perikatan (akad). Pernikahan bukan perikatan yang biasa, melainkan seperti yang termaktub pada QS. Al-Nisa: 21 adalah perikatan yang mengandung perjanjian yang kuat. Sementara itu pada QS. Al-Baqarah: 282 diterangkan adanya perintah pencatatan pada muamalah tidak secara tunai atau hutang-piutang sebagai bentuk pembuktian. Jika akad hutang-piutang perlu untuk dicatatkan, proses pernikahan pun lebih utama untuk dicatatkan. Hal ini karena akad dalam pernikahan adalah akad yang luhur dan juga sakral. Atas dasar ini, Muhammadiyah berpendapat, bahwa mencatatkan akad nikah hukumnya adalah wajib. ${ }^{19}$

Kasus penyimpangan dan wewenang yang disalahgunakan pada pernikahan faktanya sudah muncul sebelum diberlakukannya Undang-undang Perkawinan tahun 1974. Ahmad Azhar Basyir, sebagaimana dikutip Taufiqurrahman menyatakan bahwa: ${ }^{20}$

"Undang-Undang Nomor 1 Tahun 1974 tentang Perkawinan merupakan salah
satu contoh 'legislasi' atau 'pengundangan' Hukum Islam di Indonesia, yang
langsung bersumber kepada Al-Quran dan Sunah Rasul. Misalnya ketentuan
mengenai pencatatan perkawinan yang diharuskan oleh Undang-undang
Perkawinan, tidak pernah diatur atau dibicarakan dalam fikih. Tetapi dilihat dari
tujuannya, pencatatan perkawinan dapat digunakan sebagai alat bukti tertulis
yang sangat diperlukan dewasa ini, dapat dikatakan ketentuan ini sesuai dengan
ajara Al-Quran, yang mengajarkan bahwa alat bukti tertulis diperlukan dalam
soal muamalah."

Fatwa MUI yang menyatakan keharaman praktik nikah sirrî berdasar pada fenomena yang terjadi di masyarakat. Demi mewujudkan ketertiban pencatatan secara administratif oleh pemerintah perlu untuk ditaati sebagai alat bukti selain persaksian. Malthuf Siraj menyampaikan bahwa perkawinan dapat menimbulkan hak dan kewajiban serta konsekuensi sosial yang tidak sederhana. ${ }^{21}$ Seperti pemenuhan nafkah dan tempat tinggal yang layak. Berdasarkan qiyâs aulawi, Mejelis Tarjih dan Tajdid Muhammadiyah menjelaskan, apabila dalam akad muamalah -misal hutang-piutang sebagaimana tertuang di QS. Al-Baqarah: 282-

18 Majelis Ulama Indonesia, Himpunan Fatwa Majelis Ulama Indonesia Sejak 1975 (Jakarta: Sekretariat MUI, 2011), 850.

${ }^{19}$ Wawan Gunawan Abdul Wahid, "Pandangan Majelis Tarjih Dan Tajdid Muhammadiyah Tentang Nikah Sirri Dan Itsbat Nikah: Analisis Maqashid Asy-Yari'ah," MusâWa Jurnal Studi Gender Dan Islam 12, no. 1 (2013): 221-26, doi:http://dx.doi.org/10.14421/musawa.2013.122.215-236.

${ }^{20}$ Syahuri, Legislasi hukum perkawinan Indonesia, 164.

21 Malthuf Siraj, Pembaharuan Hukum Islam Di Indonesia: Telaah Kompilasi Hukum Islam (Yogyakarta: Pustaka Ilmu, 2012), 187. 
memerlukan pencatatan, maka akad nikah lebih utama dan lebih layak untuk diadakan pencatatan karena mengandung perjanjian yang agung sebagaimana firman Allah SWT dalam QS. Al-Nisa: 21.

\section{Perubahan Status Hukum Nikah Sirrî Perspektif Kaidah Fikih}

Dalam khazanah fiqh klasik, akad perkawinan dapat dihukumi mubah, sunnah, wajib, makruh, atau haram sesuai dengan konteksnya masing-masing. Jika seseorang menikah tetapi tidak mau memenuhi kebutuhan sehari-hari maka hukumnya makruh dan bisa berubah menjadi haram jika ada unsur kesengajaan. Berkenaan dengan legalitas nikah sirrî, ketentuan hukumnya bisa berubah dari makruh menjadi haram. Adapun alasan argumentatifnya sebagai berikut: Pertama, pemahaman awal nikah sirrî sebagaimana telah diketahui adalah pernikahan yang: (1) tidak dihadiri dua orang saksi, dan; (2) rukun dan syarat lengkap, namun orangtua mempelai berpesan agar saksi tidak menyebar luaskan berita pernikahan. Hukum pernikahan kategori pertama sudah jelas dinyatakan pernikahan yang batal. Kategori kedua, ulama berbeda pendapat tentang hukumnya. Mazhab Maliki menyatakan batal, Mazhab Hambali menghukumi makruh dengan akad yang sah, dan Mazhab Hanafi serta Syafii menyatakan pernikahan semacam ini tetap dianggap sah. Kedua, merujuk pada sejarah, dalam proses pernikahan tidak dikenal proses pencatatan administratif. Validitas pernikahan dicukupkan pada rukun dan syaratnya, yaitu wali dan dua orang saksi, serta ditambah dengan perhelatan upacara nikah yang jamak disebut dengan walimah. Adanya saksi dan perayaan kala itu cukup memberikan bukti otentik terjadinya pernikahan bagi kedua mempelai. Maka dapat dianggap hal tersebut sebagai proses 'pencatatan' tidak langsung terhadap prosesi pernikahan. Kebutuhan catatan tertulis dokumentatif untuk akad nikah belum dirasa perlu pada zaman dahulu. ${ }^{22}$ Demikian pula bahwa pernikahan yang terjadi pada masa lalu masih mungkin dilacak karena berada pada lingkup silsilah yang pasti. ${ }^{23}$ Tingkat penyelewengan atau penyalahgunaan wewenang pernikahan masih relatif sangat sedikit. Ahmad Rofiq menyatakan bahwa: ${ }^{24}$

"Boleh jadi karena pada waktu kitab-kitab itu ditulis tingkat amanah orang Islam relatif tinggi, sehingga kemungkinan menyalahgunakan lembaga perkawinan untuk tujuan sesaat atau sementara yang tidak sejalan dengan tujuan ideal perkawinan dan dapat merugikan pihak lain relatif kecil dan belum banyak terjadi."

Ketiga, adanya pembaharuan hukum Islam di dunia Islam. Terkhusus pada pembahasan ini adalah hukum pernikahan atau hukum keluarga. Mardani

\footnotetext{
22 Irwan Masduqi, "Nikah Sirri Dan Istbat Nikah Dalam Pandangan Lembaga Bahtsul Masail," MusâWa Jurnal Studi Gender Dan Islam 12, no. 2 (2013): 191, doi:http://dx.doi.org/10.14421/musawa.2013.122.187-200.

${ }^{23}$ Erfaniah Zuhriah and Lutfiana Dwi Mayasari, "Analisis Muatan Materi Bab XIV Kompilasi Hukum Islam Pasal 100 Tentang Pemeliharaan Anak Dan Putusan Mahkamah Konstitusi R.I. Nomor 46/PUU-VIII/2010," De Jure: Jurnal Hukum Dan Syariah 4, no. 2 (December 2012): 118, doi:10.18860/j-fsh.v4i2.2981.

${ }^{24}$ Siraj, Pembaharuan Hukum Islam Di Indonesia: Telaah Kompilasi Hukum Islam, 187.
} 
menyebutkan, minimal ada 10 materi pembaharuan dalam hukum kekeluargaan Islam, di mana salah satunya adalah masalah pendaftaran dan pencatatan perkawinan. $^{25}$ Khusus di Indonesia, proses pengaturan pernikahan oleh Taufiqurrahman Syahuri dibagi menjadi tiga periode: (1) periode sebelum kemerdekaan; (2) periode masa kepemimpinan orde lama; dan (3) periode masa kepemimpinan orde baru. ${ }^{26}$ Maka kemudian, pasca pengesahan Undang-Undang Perkawinan, terutama pada Pasal 2 ayat 2 yaitu, "Tiap-tiap perkawinan dicatat menurut peraturan perundang-undangan yang berlaku," muncullah istilah nikah sirrî yang baru. Istilah ini kemudian menjadi bahasan kaji yang ramai, terlebih pada persoalan legalitas hukum Islamnya.

Keempat, alasan pokok pada penerapan Pasal 2 ayat 2 adalah untuk menegakkan ketertiban yang menyangkut kepentingan orang banyak. ${ }^{27}$ Ketertiban tersebut diupayakan berdasarkan fakta empiris di lapangan, yaitu menyalahgunakan pernikahan yang sejatinya untuk tujuan luhur menjadi merugikan orang lain; isteri dan anak-anak. Muchsin, sebagaimana dikutip Anshary mengungkapkan kemudaratan secara umum yang terjadi pada nikah sirrî: 1) Masyarakat muslim Indonesia dipandang tidak mempedulikan kehidupan berbangsa dan bernegara dalam bidang hukum, yang pada akhirnya sampai pada anggapan bahwa pelaksanaan ajaran Islam tidak membutuhkan keterlibatan negara, yang pada akhirnya lagi mengusung pandangan bahwa agama harus dipisahkan dari kehidupan kenegaraan, yang dikenal dengan istilah sekularisme; 2) Akan mudah dijumpai perkawinan di bawah tangan, yang hanya peduli pada unsur agama saja dibanding unsur tata cara pencatatan perkawinan; 3) Apabila terjadi wanprestasi terhadap janji perkawinan, maka peluang untuk putusnya perkawinan akan terbuka secara bebas sesuka hati suami atau isteri, tanpa ada akibat hukum apa-apa, sehingga hampir semua kasus berdampak pada wanita/isteri dan anak-anak. ${ }^{28}$

Secara khusus, salah satu fakta lapangan muncul, misalnya di daerah Rembang, Jawa Tengah. Khoirul Hidayah menyebutkan bahwa perempuan yang dinikahi sirrî diperlakukan tidak adil dan tidak manusiawi. Pernikahan hanya sebatas pada rentang kecocokan, jika sudah tidak cocok maka muncul terjadi legitimasi untuk diceraikan. Akibatnya, jumlah janda bertambah, sementara anakanak mereka tidak terpenuhi kebutuhannya secara ekonomi dan tidak mendapatkan kasih saying yang utuh secara psikologis. Secara hukum, nikah sirrî memiliki resiko hukum seperti: 1) pengakuan anak; 2) nafkah anak pasca perceraian; 3) kekerasan dalam rumah tangga (KDRT). Anak hasil nikah sirrî, karena pernikahan orangtuanya tidak tecatat, menemukan kesulitan mengurus legalitas statusnya

\footnotetext{
${ }^{25}$ Mardani, Hukum perkawinan Islam di dunia Islam modern (Yogyakarta: Graha Ilmu, 2011), 94.

${ }^{26}$ Syahuri, Legislasi hukum perkawinan Indonesia, 99.

${ }^{27}$ Syahuri, Legislasi hukum perkawinan Indonesia, 173.

${ }^{28}$ H.M Anshary, Hukum perkawinan di Indonesia: masalah-masalah krusial (Yogyakarta: Pustaka Pelajar, 2010), 30.
} 
sebagai anak. Para anak hanya akan mendapatkan garis nasab ke ibunya, bukan ke ayahnya. Legalitas status anak akan merembet ke akses-akses yang berhak mereka dapatkan, seperti pendidikan. Secara ekonomi, anak-anak sirrî turut mendapat akibat dari sifat diam-diamnya sang ayah. Kerahasiaan sang ayah menafkahi anak sirrî-nya, karena khawatir diketahui isteri pertamanya, menjadikan mereka sulit menerima hak dinafakhi, sehingga istri sirrî-nya lah yang menanggung beban ekonomi. Sementara di sisi lain, nikah sirrî juga menimbulkan potensi KDRT, baik bagi istri maupun anak. Hasilnya, istri sirrî dengan mudah diceraikan begitu saja, tentu saja tanpa melalui pengadilan, karena pernikahan merekapun juga tanpa melalui pengadilan. ${ }^{29}$

Berdasarkan runtutan di atas, maka perubahan hukum atau bahkan penemuan hukum baru terhadap nikah sirrî dapat terjadi. Hal ini sebagaimana pandangan fatwa yang dikemukakan baik oleh MUI ataupun Muhammadiyah. Terlebih MUI menegaskan bahwa nikah sirrî bisa saja menjadi haram apabila muncul kemudaratan. Ahmad Mustofa Maraghi, sebagaimana dikutip Mardani, mengemukakan: ${ }^{30}$

"sesungguhnya hukum-hukum itu diundangkan untuk kepentingan manusia dan kepentingan manusia itu tidak sama satu dengan yang lainnya karena ada perbedaan waktu dan tempat. Apabila suatu hukum yang diundangkan itu pada saat dibuat dipandang sebagai suatu kebutuhan, kemudian pada saat yang lain kebutuhan akan hukum itu sudah tidak ada lagi, maka adalah suatu tindakan bijaksana untuk menghapus hukum itu dan menggantikannya dengan hukum yang baru yang lebih sesuai dengan tuntutan zaman."

Karena itulah proses pencatatan nikah menjadi hal yang perlu diijtihadi. Menjadi maklum kemudian ketika disimpulkan pencatatan menjadi wajib untuk dilaksanakan. Terlebih lagi hal itu sudah menjadi ketatapan undang-undang, di mana dalam QS. Al-Nisa: 59 umat Islam diminta untuk taat kepada pemimpin negara. Demikian pula bahwa proses pencatatan ini diberlakukan untuk kemaslahatan dan kemanfaatan masyarakat dalam mengatur kehidupan mereka. Maka, berdasarkan pada kewajiban pencatatan tersebut, fatwa MUI yang menyatakan haram nikah sirrî apabila ada kemudaratan dapat diambil sebagai dasar perubahan hukum. Demikian pula penerapan kaidah "Tidak diingkari perubahan hukum karena perubahan zaman (lā yunkaru taghayyuru al-ahkām bitaghayyuri alazmān) pada praktik nikah sirrî dapat dimaklumi sebagai upaya pembaruan hukum berdasarkan pada kemanfaatan dan kemaslahatan, sesuai dengan ajaran agama Islam.

\section{Kesimpulan}

${ }^{29}$ Hidayah, "Persoalan Hukum Perempuan Rembang Akibat Praktek Nikah Sirri," 87 \& 92-94.

${ }^{30}$ Mardani, Hukum perkawinan Islam di dunia Islam modern, 96. 
Berdasarkan kaidah fikih "Tidak diingkari perubahan hokum karena perubahan zaman, maka perubahan hukum nikah sirrî dapat dilihat melalui strukturnya. Pada mulanya, nikah sirrî memiliki dua jenis hakikat yang berbeda, yaitu tanpa saksi dan wasiat untuk menyembunyikan kabar pernikahan. Duaduanya jika ditilik dari hikmah disyariatkannya pernikahan membawa dampak yang negatif dan untuk itu dihukumi sebagai suatu hal yang tidak boleh. Ini wajar karena memang secara praktik dapat disimpulkan tidak sesuai secara syariat. Seperti halnya yang disampaikan Mahmud Syaltut, "pernikahan yang dibayang-bayangi kegelisahan jika diketahui orang lain tidaklah mungkin menjadi pernikahan yang syar'i di mana Allah menjadikannya sebagai sakînah, mawaddah, dan rahmah. Maka pada masa lalu, seseorang yang melakukan akad nikah sesuai rukun dan syaratnya adalah pernikahan yang sah, meskipun tidak ada atau belum dikenal dokumentasi nikah secara tertulis. Sementara pada masa dikenalkannya dokumentasi pernikahan secara tertulis, praktik menikah memiliki 'tambahan syarat' yang harus dilakukan. Bahwa negara dalam rangka mengatur tata administratif warganya memerlukan rekam dokumen yang dapat dijadikan sebagai pegangan formil. Karena itulah, kewajiban mencatatkan pernikahan menjadi urgensi tersendiri yang pada akhirnya menjadikan pernikahan yang tidak tercatat sebagai hal yang perlu diwanti-wanti. Lebih-lebih secara fakta tidak dicatatkannya prosesi nikah menimbulkan dampak negatif yang merugikan keluarga.

Atas dasar tersebut, perlu adanya upaya penegasan dari pemerintah terhadap praktik nikah sirrî. Atas dasar itu pula perlu adanya sosialisasi intensif dari pemerintah kepada masyarakat tentang kemudaratan yang lebih besar timbul daripada sisi kemanfaatannya. Hal ini agar supaya hal-hal yang merugikan tidak terjadi di tengah-tengah masyarakat hingga menimbulkan ketidaktertiban dalam kehidupan sosial. Pada ranah penelitian perlu kiranya pengembangan studi terkait dengan keterlanjuran nikah sirrî oleh masyarakat dan upaya pemerintah dalam penanganannya. Contoh yang mungkin bisa digali regulasinya adalah ihwal batasan waktu tolerir nikah sirrî jika dijumpai keterpaksaan. Studi tersebut akan memberikan manfaat yang cukup dalam rangka meminimalisir praktik sirrî dalam perkawinan di Indonesia. 


\section{Daftar Pustaka:}

Al-Bahisin, Ya'qub bin Abdul Wahab. Al-Mufasshal Fi Al-Qawâ'id Al-Fiqhiyyah. Darut Tadammuriyah, 2011.

Al-Kasani, Alauddin. Badâi' Al-Shanâai' Fî Tartîb Al-Syarăi'’ Vol. 2. Beirut: Darul Kitab Al-Arabi, 1982.

Al-Marwazi, Abu Ya'qub Al-Tamimi. Masầilu'l Imâm Ahmad Bin Hanbal Wa Ibni RâHawaih. Riyadh: Darul Hijrah, 2004.

Al-Mawardi, Ali bin Muhammad bin Habib. Al-HâWîu'l Kabîr Fî Fiqh Madzhabi'l Imâm Al-SyâFi'i. Vol. 9. Beirut: Darul Kutub Ilmiah, 1999.

Al-Qurthubi, Muhammad bin Ahmad bin Muhammad bin Ahmad bin Rusyd. BidâYah Al-Mujtahid Wa NihâYah Al-Muqtashid. Vol. 2. Darul Ma'rifah, n.d.

Al-Zarqa, Ahmad bin Muhammad. Syarh Al-Qawâaid Al-Fiqhiyyah. Damaskus: Darul Qalam, 1989.

Anshary, H.M. Hukum perkawinan di Indonesia: masalah-masalah krusial. Yogyakarta: Pustaka Pelajar, 2010.

Anshori, Abdul Ghofur. Hukum perkawinan Islam: perspektif fikih dan hukum positif. Yogyakarta: UII Press, 2011.

Arsal, Thriwaty. "Woman's Position in Undocumented Marriages." Jurnal Komunitas: Research and Learning in Sociology and Anthropology 6, no. 1 (June 12, 2014). doi:10.15294/komunitas.v6i1.2947.

Baihaqi, Abu Bakar Ahmad ibn Husain ibn Ali al-. Al-Sunanu'l Kubra. Vol. 7. Makah: Darul Baz, 1994.

Dardir, Sayid Ahmad. Al-Syarhu'l Kabîr. Vol. 2. Beirut: Darul Fikri, n.d.

Hidayah, Khoirul. "Persoalan Hukum Perempuan Rembang Akibat Praktek Nikah Sirri." De Jure: Jurnal Hukum Dan Syariah 3, no. 1 (June 2011). doi:10.18860/j-fsh.v3i1.1322.

Ibnu Majah. Sunan Ibnu Majah. Vol. 1. Beirut: Darul Fikri, n.d.

Kementrian Wakaf dan Agama Islam Kuwait. Al-Mausû'atul Fiqhiyyah. Vol. 41. Kuwait: Dar Al-Salasil, 2002.

Majelis Ulama Indonesia. Himpunan Fatwa Majelis Ulama Indonesia Sejak 1975. Jakarta: Sekretariat MUI, 2011.

Mardani. Hukum perkawinan Islam di dunia Islam modern. Yogyakarta: Graha Ilmu, 2011.

Masduqi, Irwan. "Nikah Sirri Dan Istbat Nikah Dalam Pandangan Lembaga Bahtsul Masail.” MusâWa Jurnal Studi Gender Dan Islam 12, no. 2 (2013). doi:http://dx.doi.org/10.14421/musawa.2013.122.187-200.

Masturiyah. "Nikah Sirri: Prespektif Hukum Islam Dan Hukum Perkawinan Nasional." MusâWa Jurnal Studi Gender Dan Islam 12, no. 1 (2013). doi:http://dx.doi.org/10.14421/musawa.2013.121.43-62.

Nuruddin, Amiur, and Azhari Akmal Tarigan. Hukum perdata Islam di Indonesia: studi kritis perkembangan hukum Islam dari fikih, UU no. 1/1974, sampai KHI. Jakarta: Kencana, 2004.

Siraj, Malthuf. Pembaharuan Hukum Islam Di Indonesia: Telaah Kompilasi Hukum Islam. Yogyakarta: Pustaka Ilmu, 2012. 
12 | De Jure: Jurnal Hukum dan Syari'ah, Vol. 9 No. 1 Tahun 2017

Syahuri, Taufiqurrohman. Legislasi hukum perkawinan Indonesia: pro-kontra pembentukannya hingga putusan Mahkamah Konstitusi. Jakarta: Kencana, 2013.

Syaltut, Mahmud. Al-Fatâwâ (DirâSah Li MusykilâTi'l Muslimi'l Mu'âShir Fî HayâTihi'l Yaumiyati'l 'Âmmah). Kairo: Al-Syuruq Pers, 2004.

Wahid, Wawan Gunawan Abdul. "Pandangan Majelis Tarjih Dan Tajdid Muhammadiyah Tentang Nikah Sirri Dan Itsbat Nikah: Analisis Maqashid Asy-Yari'ah.” MusâWa Jurnal Studi Gender Dan Islam 12, no. 1 (2013). doi:http://dx.doi.org/10.14421/musawa.2013.122.215-236.

Zuhriah, Erfaniah, and Lutfiana Dwi Mayasari. "Analisis Muatan Materi Bab XIV Kompilasi Hukum Islam Pasal 100 Tentang Pemeliharaan Anak Dan Putusan Mahkamah Konstitusi R.I. Nomor 46/PUU-VIII/2010.” De Jure: Jurnal Hukum Dan Syariah 4, no. 2 (December 2012). doi:10.18860/jfsh.v4i2.2981. 